\title{
GEOGRAPHICAL DISTRIBUTION AND INTRA-DOMICILIARY CAPTURE OF SYLVATIC TRIATOMINES IN LA CONVENCIÓN PROVINCE, CUSCO, PERU
}

Dina Beatriz TORRES V.(1) \& Rufino CABRERA(2)

\begin{abstract}
SUMMARY
The geographical distribution and intra-domiciliary capture of sylvatic triatomines in three districts of the province of La Convención, Cusco, Peru are presented. In the district of Vilcabamba, eight adults of Rhodnius pictipes and five adults of Panstrongylus geniculatus were found. In the district of Ocobamba, 19 adults, 14 nymphs, and eggs of $P$. rufotuberculatus were found. In the district of Echarate, six adults and 10 nymphs of Eratyrus mucronatus, an adult of $R$. pictipes and $P$. geniculatus, and a nymph of $P$. rufotuberculatus were also found. The geographical distribution of E. mucronatus has extended to Cusco. This is the first report in Peru of household colonization by this triatomine.
\end{abstract}

KEYWORDS: Triatominae; Panstrongylus; Rhodnius; Eratyrus; Peru.

Chagas disease, caused by the hemoflagellate protozoan, Trypanosoma cruzi, is transmitted to humans mainly by contact with hematophagous triatomines feces ${ }^{16}$.

In Peru, the number of people estimated to be infected by $T$. cruzi is between 650000 and $670000^{6}$. The endemic area is stratified in three eco-epidemiological regions (Southwest, Andean and Amazon) ${ }^{2}$. Cusco is one of the departments that belong to this last region. Triatomines reported in this region are Panstrongylus rufotuberculatus (Champion, 1899), Microtriatoma trinidadensis (Lent, 1951) and Rhodnius pictipes (Stål, 1872) ${ }^{4}$; Triatoma infestans $(\mathrm{Klug}, 1834)^{10}$; and P. geniculatus $\left(\right.$ Latrielle, 1811) ${ }^{12}$. The last one has been found only in the province of La Convención valley.

P. rufotuberculatus is a sylvatic triatomine that infests $38 \%$ of the localities in the district of Ocobamba, La Convención, where its domiciliation was reported for the first time in Peru by CALDERÓN et $a l .{ }^{4}$. Domestic colonies have also been documented in bedrooms and are associated with guinea pig breeding in the district of Suyo in Piura department and its synanthropic behavior has also been observed in Tumbes ${ }^{13}$. Tendency of sylvatic triatomines towards domiciliation is very important to identify areas at high risk of $T$. cruzi transmission and to implement prevention and control measures against Chagas disease.

The objective of this report is to show the geographical distribution and intra-domiciliary capture of sylvatic triatomines in three districts of La Convención, Cusco, Peru.

The department of Cusco is located in the southeast part of Peru. It has 13 provinces, the largest of which is La Convención with 10 districts. Vilcabamba is a rural area; $71.4 \%$ of the dwellings' walls in Vilcabamba are made of adobe and $12.5 \%$ are wooden ${ }^{9}$. Ocobamba is mainly rural. Almost nine of each 10 dwellings (88.9\%) in the district have walls of adobe and only $6.4 \%$ are wooden ${ }^{9}$. In Echarate, $82.2 \%$ of the population lives in the rural area and $26.6 \%$ of the inhabitants are immigrants 9 . The dwellings are scattered. The communities evaluated (Fig. 1) produce coffee, coca, cacao, achiote and bananas. The localities of the studied districts belong to the tropical rain forest and tropical wet forest ecoregions ${ }^{17}$, where the mean temperature ranges between $15^{\circ}$ to $26^{\circ} \mathrm{C}$, and the annual precipitation ranges between 1275 to $3000 \mathrm{~mm}$.

Triatomine adults, nymphs and eggs were collected by community health promoters and health technicians inside houses of 13 communities between January 2006 and March 2009. In the first case the collection was passive, when villagers notified a triatominae finding in the domestic environment of households. The last case was a manual search during house visits for malaria control and prevention activities. Most bugs were collected passively. Triatomines were classified and identified utilizing the key of LENT \& WYGODZINSKY (1979) ${ }^{11}$. The nymphs of Eratyrus and of Panstrongylus that arrived alive to the laboratory were raised to adulthood, and then identified. Voucher specimens were deposited in the Museum of Entomology, Universidad Agraria La Molina, Lima, Peru (UA), with the codes UA- 140-2008 R. pictipes, 117-2006 P. geniculatus, 118-2006 P. rufotuberculatus and 054-2009 E. mucronatus (Stål, 1859).

Only live or recently dead bugs were examined microscopically for the presence of Trypanosomes. For the microscropic examination, intestinal contents of the insects were obtained by abdominal pressure. 
TORRES V., D.B. \& CABRERA, R. - Geographical distribution and intra-domiciliary capture of sylvatic triatomines in La Convención Province, Cusco, Peru. Rev. Inst. Med. Trop. Sao Paulo, 52(3):157-60, 2010.

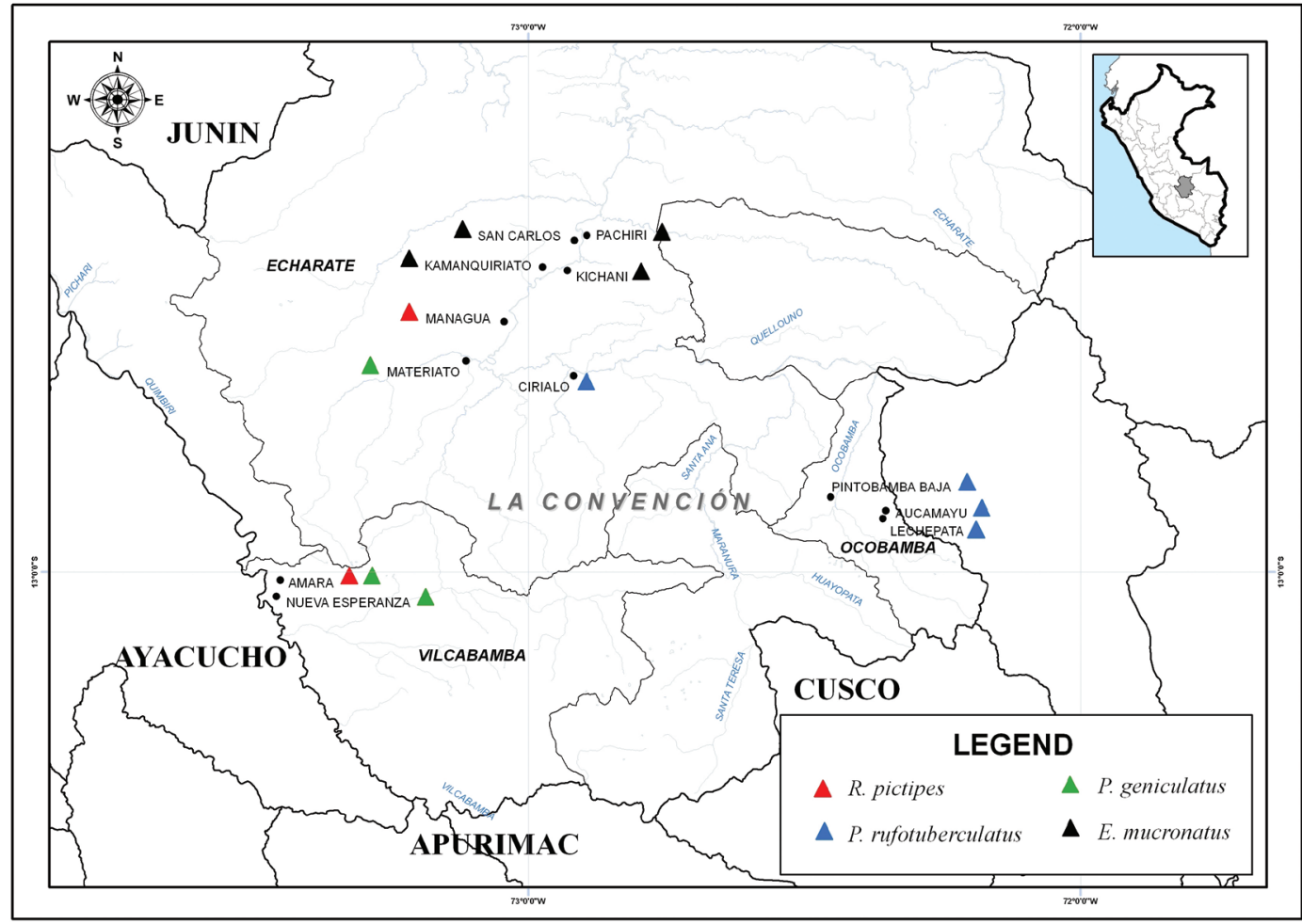

Fig. 1 - Sylvatic triatomine distribution in communities in La Convención province, Cusco, Peru.

P. rufotuberculatus domestic colonies were also found in the bedroom and dining room of dwellings in the Ocobamba district. In the district of Echarate in San Carlos community a colony of E. mucronatus was found in a bedroom; and two fifth instar nymphs were found in Kamanquiriato. The structure by instar and other characteristics are presented in Table 1. Less than $10 \%(6 / 64)$ of the samples were examined for natural infection by $T$. cruzi; none were positive.

$R$. pictipes is a sylvatic vector associated with palm trees, and has broad distribution in South America ${ }^{8}$. In Peru, it can be found in the departments of Loreto, Ucayali, Madre de Dios, Huánuco, Junín, Ayacucho, San Martín, and Cusco ${ }^{5,10}$, in the province of Quispicanchis ${ }^{5,10}$. In this report its distribution is extended to the province of La Convención (Vilcabamba and Echarate). In Huayobamba valley two intradomestic colonies have been found ${ }^{4}$ and also in Pachizilla, in the province of Juanjuí, department of San Martín. It has been classified as a species in advance domiciliation ${ }^{10}$. We have found adults only, all within human dwellings. This species presents high rates of natural infection by $T$. cruzi in other countries.

The finding of $P$. geniculatus clarifies the geographical distribution of this species in La Convención (Vilcabamba and Echarate); previously it had been reported without mentioning either the district or the locality ${ }^{12}$. It is widely distributed in 11 other departments of Peru (Cajamarca, Pasco, Huánuco, Junín, Ayacucho, Puno, Amazonas, San Martín, Loreto, Ucayali, Madre de Dios) ${ }^{5,10}$. It is strictly sylvatic, and has been associated with an acute case of Chagas disease in the central jungle of Peru ${ }^{19}$. Nevertheless, CÁCERES et al. (2002) $)^{3}$, consider it to have a tendency to colonize the dwellings. They collected 95 adults in $8 / 15$ districts evaluated in Cajamarca and in 9/12 districts in Amazonas, finding 87\% of them inside the dwellings. We found six adults and all were found inside the domestic environment.

P. rufotuberculatus is a sylvatic species that is distributed in 10 countries of the Americas, among them, Peru ${ }^{8}$. Its presence has been reported in Cajamarca, Junín, Piura, Puno and $\mathrm{Cusco}^{5,10}$.

The first report in Peru of domiciled colonies by P. rufotuberculatus, including eggs, was made in Ocobamba valley, La Convención (Cusco) ${ }^{4}$, with a household infestation rate of $38.3 \%$ (66/172). We corroborated intradomestic infestation in three localities of Ocobamba, and in addition, its geographic distribution was extended to the community of Cirialo in the district of Echarate. The synanthropic tendency of this species has been described in Suyo district, Ayabaca province (Piura), where it has been associated with guinea pig breeding having been proposed that these are stable colonies and its synanthropic behavior has also been observed in Tumbes ${ }^{13}$. The altitudinal dispersion in Ocobamba is similar to what has previously been reported, between 1200 to 1900 meters above sea level ${ }^{4}$. In Echarate, we have found the organism at 750 meters above sea level. These areas belong to the eco-regions of tropical rain forest and tropical wet forest, unlike the registries in Piura at 530 meters above sea level ${ }^{13}$, in tropical dry forest.

Its capacity for colonization has also been documented in the district of Carrasco, province of Nor Yungas, subtropical forest, located at 1500 meters above sea level ${ }^{14}$; in Muñecas department, La Paz, Bolivia ${ }^{7}$; and also in southern Ecuador ${ }^{1}$. In a community in the municipality of Amalfi, Antioquia, Colombia, 94 specimens in all instars were found in three 
TORRES V., D.B. \& CABRERA, R. - Geographical distribution and intra-domiciliary capture of sylvatic triatomines in La Convención Province, Cusco, Peru. Rev. Inst. Med. Trop. Sao Paulo, 52(3):157-60, 2010.

Table 1

Structure by development stage and ecotopes of the sylvatic triatomines species identified in La Convención, Cusco, Peru

\begin{tabular}{|c|c|c|c|c|c|c|}
\hline \multirow{2}{*}{ District } & \multirow{2}{*}{ Locality } & \multirow{2}{*}{$\begin{array}{l}\text { Altitude } \\
\text { (MASL) }\end{array}$} & \multirow{2}{*}{ Species } & \multirow{2}{*}{ Triatomines instar } & \multicolumn{2}{|c|}{ Ecotopes } \\
\hline & & & & & Wall & Roof \\
\hline \multirow[t]{3}{*}{ Vilcabamba } & Amara (Chancavine sector) & 1000 & $R$. pictipes & Adult $\left(7+, 1 \delta^{\lambda}\right)$ & Wooden & Zinc \\
\hline & Nueva Esperanza & 1100 & P. geniculatus & Adult (1ठ) & Wooden & Zinc \\
\hline & Amara & 1100 & & Adult ( $3 \propto$ a and $1 \delta)$ & Wooden & Zinc \\
\hline \multirow[t]{3}{*}{ Ocobamba } & Pintobamba Baja & 1400 & P. rufotuberculatus & Adult $\left(8+, 3 \circlearrowleft^{\lambda}\right)$, Nymphs (3 IV, 1 III), eggs & Adobe & Zinc \\
\hline & Lechepata & 1450 & & $\begin{array}{l}\text { Adult }\left(2+, 1{ }^{\nwarrow}\right), \text { Nymphs ( } 1 \text { of V, } 1 \text { of III, } \\
1 \text { of II), eggs }\end{array}$ & Adobe & Zinc \\
\hline & Aucamayu & 1450 & & $\begin{array}{l}\text { Adult }\left(3 \circ, 2{ }^{\Uparrow}\right), \text { Nymphs ( } 2 \text { of } \mathrm{V}, 1 \text { of IV, } \\
1 \text { of III, } 1 \text { of II and } 2 \text { of I) }\end{array}$ & Adobe & Zinc \\
\hline \multirow[t]{7}{*}{ Echarate } & San Carlos & 600 & E. mucronatus & $\begin{array}{l}\text { Adult }\left(3+, 1 \delta^{\Uparrow}\right), \text { Nymphs ( } 1 \text { of IV, } 3 \text { of } \mathrm{V}, \\
4 \text { were deteriorated). }\end{array}$ & Wooden & Zinc \\
\hline & Kamanquiriato & 600 & & 2 V Nymphs & Wooden & Zinc \\
\hline & Pachiri & 550 & & Adult (1우) & Wooden & Zinc \\
\hline & Kichani & 500 & & Adult (1ㅇ) & Wooden & Zinc \\
\hline & Managua & 600 & R. pictipes & Adult $\left(1 \delta^{\Uparrow}\right)$ & Adobe & Zinc \\
\hline & Cirialo & 750 & P. rufotuberculatus & $1 \mathrm{~V}$ Nymph & Adobe & Zinc \\
\hline & Materiato & 600 & P. geniculatus & Adult (1ठ) & Adobe & Zinc \\
\hline
\end{tabular}

MASL $=$ meters above sea level.

rural dwellings. Hatched eggs and exuviae were also found. The rate of natural infection by $T$. cruzi was $4.6 \%{ }^{20}$. We found similar hatched and fertilized eggs and exuviae. It is important to determine its distribution in other areas of the province of La Convención, in order to determine its degree of domiciliation with the purpose of setting up chemical control against this vector.

We document for the first time in Peru the domiciliation of $E$. mucronatus, due to the finding of domiciliated colonies; however, a domiciliated colony had already been observed in September 1975, in rustic housing in the locality of Urcupata, province of Lamas, San Martin (W. Dale, "unpublished observations"), UA 59-76. The synanthropic behavior of this insect has also been described in Los Caprichos, Felipe M. Cañizales Municipality, State of Trujillo (Venezuela), by the finding of second and third instar nymphs under the bed ${ }^{18}$. Nevertheless, we found triatomines in adult stage which differ from the population structure reported by the Venezuelan authors. Colonies of E. mucronatus have also been found in domestic and peridomestic environments in Apolo, department of La Paz, Bolivia. From 68 collected specimens 19.1\% were naturally infected by $T$. cruzi and in two dwellings E. mucronatus was associated with $T$. sordida infestation ${ }^{15}$. We did not find instar I nymphs.

The geographical distribution of E. mucronatus has extended to Cusco, province of La Convención, in localities between 500 to 600 meters above sea level. It has been previously reported in Loreto, Ucayali, San Martín, Madre de Dios, and Junín; in the first four it has been found infected by $T$. cruzi $i^{5,10}$; although, it has been considered as of little epidemiological importance for Peru ${ }^{6}$. However, the finding of domiciled colonies both in La Convención (Cusco) and in Lamas (San Martín) can change the status of this species. Due to the destruction of its natural habitats, it can easily adapt to stable artificial ecotopes ${ }^{18}$. The presence of $E$. mucronatus in dwellings surrounded by coffee, cacao and banana plantations suggests that this species has the ability to adapt to anthropic action.

In order to determine its role in the transmission of Chagas disease, it is important to determine the natural infection rate by $T$. cruzi in the four triatomine species reported in this essay.

It seems that there is no preference for adobe or wood among sylvatic species reported, but in future studies of domiciliation it is important to describe the characteristics of ecotopes in order to better understand the vector's capacity to adapt to artificial structures.

Concerning the limitations of this report, it is important to mention that a T. cruzi natural infection test was carried out only in $9.3 \%$ of specimens, due to limitation in access to an adequate laboratory and the majority of the samples having arrived already dead. Also, the samples 
TORRES V., D.B. \& CABRERA, R. - Geographical distribution and intra-domiciliary capture of sylvatic triatomines in La Convención Province, Cusco, Peru. Rev. Inst. Med. Trop. Sao Paulo, 52(3):157-60, 2010.

are the product of a passive collection method, which is very likely to underestimate the infestation prevalence and its distribution. Therefore, it is important to search for triatomines with active collection methods and to collect a bigger sample, involving inspection in domestic and sylvatic ecotopes as well as diverse periods of the year, in order to know the circulation of $T$. cruzi. We suggest the implementation of a system of entomological surveillance in La Convención with community participation.

The number of triatomines species described in the department of Cusco, including the findings in this report, is increased to six, and to four in the province of La Convención.

\section{RESUMO}

\section{Distribuição geográfica e captura intra-domiciliar de triatomíneos silvestres na província de La Convención, Cusco, Peru}

Apresenta-se a distribuição geográfica e captura intra-domiciliar de triatomíneos silvestres em três distritos da província de La Convención, Cusco, no Peru. Foram encontrados oito adultos de Rhodnius pictipes e cinco adultos de Panstrongylus geniculatus, no distrito de Vilcabamba, 19 adultos, 14 ninfas e ovos de $P$. rufotuberculatus no distrito de Ocobamba. Também foram encontrados seis adultos e 10 ninfas de Eratyrus mucronatus, um adulto de $R$. pictipes e $P$. geniculatus, e uma ninfa de $P$. rufotuberculatus no distrito de Echarate. A distribuição de $E$. mucronatus amplia-se geograficamente a Cusco. Este é o primeiro relato de domiciliação por este triatomíneo no Peru.

\section{ACKNOWLEDGMENTS}

To Gregorio Umeres Azorsa, Edgar Sánchez Jiménez, Guadalupe Sosa Montañez, José Luis Bocangel, Marlene Ayma Condori, Rogelia Cárdenas Díaz from the Health Posts of Red de Salud La Convención, for the collection of the specimens. To Dr. William Dale Larrabure from Universidad Agraria La Molina, Lima.

\section{REFERENCES}

1. Abad-Franch F, Paucar CA, Carpio CC, Cuba CCA, Aguilar VMH, Miles MA. Biogeography of Triatominae (Hemiptera: Reduviidae) in Ecuador: implications for the design of control strategies. Mem Inst Oswaldo Cruz. 2001;96:611-20.

2. Cabrera CR. Enfermedad de Chagas o Trypanosomiasis Americana. In: Suárez Ol, Beingolea ML, Nakamoto TI, Cabrera CR, editors. Protocolos de vigilancia epidemiológica. Parte I. $2^{\text {nd }}$ ed. Lima: Dirección General de Epidemiología, Ministerio de Salud; 2006. p. 89-114

3. Cáceres GA, Troyes L, Gonzáles-Pérez A, Llontop E, Bonilla C, Murias E. Enfermedad de Chagas en la región nororiental del Perú. I. Triatominos (Hemiptera, Reduviidae) presentes en Cajamarca y Amazonas. Rev Peru Med Exp Salud Publica. 2002;19:1723.

4. Calderón G, Cuzquén L, Figueroa KE, Náquira F. Perú. In: Carcavallo RU Rabinovich JE, Tonn RJ, editors. Factores biológicos y ecológicos en la enfermedad de Chagas. Tomo II. Buenos Aires: Ministerio de Salud y Acción Social de Argentina, Centro Panamericano de Ecología Humana y Salud; 1985. p. 449-55.
5. Chávez J. Contribución al estudio de los triatominos del Perú: distribución geográfica, nomenclatura y notas taxonómicas. An Fac Med (Peru). 2006;67:65-76.

6. Cuba-Cuba C, Abad-Franch F, Roldan RJ, Vargas VF, Pollack VL, Miles MA. The triatomines of northern Peru, with emphasis on the ecology and infection by trypanosomes of Rhodnius ecuadoriensis (Triatominae). Mem Inst Oswaldo Cruz. 2002;97:175-83.

7. Dujardin JP, Forgues G, Torrez M, Martinez E, Córdoba C, Gianella A. Morphometric of domestic Panstrongylus rufotuberculatus in Bolivia. Ann Trop Med Parasitol. 1998;92:219-28.

8. Galvão C, Carcavallo R, Da Silva RD, Jurberg J. A checklist of the current valid species of the subfamily Triatominae Jeannel, 1919 (Hemiptera, Reduviidae) and their geographical distribution, with nomenclatural and taxonomic studies notes. Zootaxa. 2003;202:1-36.

9. Instituto Nacional de Estadística e Informática. Perú: Censos Nacionales 2007, XI de Población y VI de Vivienda. Lima: Instituto Nacional de Estadística e Informática; c2002-2009, 2007 Available from: http://censos.inei.gob.pe/Censos2007/IndDem/ [cited 2009 Jun 1].

10. Instituto Nacional de Salud. Distribución de los principales vectores de enfermedades del Perú. Lima: Instituto Nacional de Salud, Ministerio de Salud; 2002.

11. Lent H, Wygodzinsky P. Revision of the Triatominae (Hemiptera, Reduviidae), and their significance as vectors of Chagas' disease. Bull Am Mus Nat His. 1979;163:123-520.

12. Magalhães dos Santos C, Jurberg J, Galvão C, Da Silva Rocha D, Rodriguez FJI. Estudo morfométrico do gênero Panstrongylus Berg, 1879 (Hemiptera, Reduviidae, Triatominae). Mem Inst Oswaldo Cruz. 2003;98:939-44

13. Marin E, Santillán R, Cuba C, Jurberg J, Galvâo C. Hallazgo de Panstrongylus rufotuberculatus (Champion, 1899) (Hemiptera, Reduviidae, Triatominae) en ambiente domiciliario en la Región Piura, Perú. Cad. Saúde Pública, 2007;23:2235-8.

14. Noireau F, Vargas F, Bosseno MF, Brenière SF. Apparent trend to domesticity observed in Panstrongylus rufotuberculatus (Hemiptera: Reduviidae) in Bolivia. Res Rev Parasitol. 1994;54:249-50.

15. Noireau F, Bosseno MF, Carrasco R, Telleria J, Vargas F, Camacho C, et al. Sylvatic triatomines (Hemiptera: Reduviidae) in Bolivia: trends toward domesticity and possible infection with Trypanosoma cruzi (Kinetoplastida: Trypanosomatidae). J Med Entomol. 1995;32:594-8.

16. Prata A. Clinical and epidemiological aspects of Chagas disease. Lancet Infect Dis. 2001;1:92-100.

17. Rodríguez LO, Young KR. Biological diversity of Peru: determining priority areas for conservation. Ambio. 2000;29:329-37.

18. Soto-Vivas A, Barazarte H, Molina De Fernández D. Primer registro de Eratyrus mucronatus Stal, 1959 (Hemiptera: Reduviidae) en el ambiente domiciliario en Venezuela. Entomotropica. 2001;16:215-7.

19. Vega S, Mendoza A, Cabrera R, Cáceres GA, Campos E, Campos E, et al. Primer caso de enfermedad de Chagas aguda en la selva central del Perú: investigación de colaterales, vectores y reservorios. Rev Peru Med Exp Salud Pública. 2006;23:288-92.

20. Wollf M, Castillo D. Domiciliation trend of Panstrongylus rufotuberculatus in Colombia. Mem Inst Oswaldo Cruz. 2002;97:297-300.

Received: 18 January 2010

Accepted: 18 March 2010 